\section{Gerard Thomas Corley Smith}

30 July 1909 - 7 October 1997

My first meeting with 'Corley' as he was widely known in the conservation world, was on board the royal yacht Britannia in the Galápagos Islands, an appropriate place to meet someone who was to play such an important role in the protection of those unique islands. Corley was the British Ambassador to Ecuador at the time, and was fortunate enough to have two opportunities to visit the islands in an official capacity. Visiting Galápagos in 1964 was not easy; there was no airline connection and a 4-5 day boat trip was the norm. Had it not been for the official opening of the Charles Darwin Research Station in January 1964 and Prince Philip's visit in November of the same year, Corley might not have made it to the islands at all.

Having been given the opportunity, Corley characteristically seized it with both hands and devoted much of his retirement to the Galápagos, becoming the Secretary General of the Charles Darwin Foundation in 1972 and producing 24 copies of its magazine, Noticias, over the next 10 years.

The Charles Darwin Foundation was set up in 1959 by Jean Dorst, Sir Julian Huxley, Peter Scott and others with a view to gathering scientific information to help the Ecuadorian Government preserve the amazing biodiversity and ecosystem of the archipelago. The fact that some 95 per cent of that biodiversity is still intact, is in no small part due to the efforts of the Foundation over the years and of Corley during his terms as Ambassador and Secretary General of the Foundation.

Corley's first contact with the Charles Darwin Foundation came soon after his appointment as Ambassador to Ecuador. The capital, Quito, is at an altitude of some $3230 \mathrm{~m}$ and Corley developed an interest in, and wrote a paper on, a high-altitude hummingbird (Oreotrochius chimborazo jamesoni), which brought him to the attention of Jean Dorst, then president of the Charles Darwin Foundation. His experience as an Ambassador gave him a very specific insight into the role of the foreign community in helping the government and people of Ecuador to look after the Galápagos. Rather than walking in and telling them what to do, a course of action guaranteed to upset a proud and independent nation, Corley was well aware of the need to provide advice and assistance and to encourage the Ecuadorians to take responsibility for the protection, and for the controlled and sustainable development, of the islands. The Ecuadorian Government recognized his contribution by awarding him the Order Al Merito on his retirement from the Foundation.

Corley was very much his own man and, while being a diplomat, was not afraid to stand up for what he felt was right. This earned him the opprobrium of Eastern-bloc delegates at the UN Economic and Social Council in New York in 1949 and of Papa Doc, Duvalier, who had him thrown out of Haiti in 1961. His fortuitous appointment to Ecuador followed and we must all be grateful for that.

Corley also played his part in the wider conservation scene, serving as a Council Member for FFI (then FPS) from June 1969 until he retired in September 1981, giving the society the full benefit of his deep love for ornithology and the Galápagos, coupled with his wide experience as a diplomat. His final contribution as a conservationist came when I was helping to establish the Galápagos Conservation Trust, a UK-registered charity established to help conserve the islands and to support the Charles Darwin Foundation. I invited him to be a Vice-President and even though he described himself as a 'busted flush', his contribution and support were still of immense value, and his experience and advice always relevant and helpful.

His family, friends, colleagues and the Galápagos Islands will miss him greatly. His contribution to the conservation of the islands will stand as a lasting memorial to a warm, friendly, humorous and very individual man. What better epitaph could there be than the inscription written by Jean Dorst in Corley's copy of Dorst's The Life of Birds, 'To remember him our fights for Galapagos'.

Julian Fitter 